\title{
Molecular confirmation of Xiphinema italiae Meyl, 1953 (Nematoda: Longidoridae) from the Slovak Republic
}

\author{
S. KUMARI ${ }^{1}$, M. LIŠKOVÁ ${ }^{2}$ \\ ${ }^{1}$ Crop Research Institute, Division of Plant Health, Drnovská 507, Ruzyně, 16106 Prague 6, Czech Republic, \\ E-mail: kumari@vurv.cz; ${ }^{2}$ Parasitological Institute, Slovak Academy of Sciences, Hlinkova 3, 04001 Košice, \\ Slovak Republic, E-mail: liskova@saske.sk
}

\begin{abstract}
Summary
Identification of the nematode Xiphinema italiae relies mainly on time-consuming morphological and morphometrical studies. A polymerase chain reaction protocol has been used for the reliable and specific identification of $X$. italiae. Moreover, four independently evolving molecular markers (coxl- cytochrome $c$ oxidase subunit 1; ITS2second internal transcribed spacer; $18 \mathrm{~S}$ gene and D2/D3 expansion segments of $28 \mathrm{~S}$ gene) were amplified and sequenced in both directions.
\end{abstract}

Keywords: Xiphinema italiae; PCR; ITS2; cox1; 18S; 28S

\section{Introduction}

Xiphinema italiae Meyl, 1953 is widespread migratory plant parasitic nematode species occurring in southern and central Europe, i.e. in Bulgaria (Peneva \& Choleva, 1992), France (Wang et al., 2003), Greece (Tzortzakakis et al., 2006), Hungary (Nagy, 1999), Italy (Martelli et al., 1966), Moldavia (Polinovskij, 1979), Serbia (Barsi \& Lamberti, 2003), Slovakia (Liškova et al., 1993) and Spain (Teliz et al., 2007). It was recorded also in Moscow area of Russia (Romanenko, 1985). Outside Europe it was found in Cuba (Dias-Silveira \& Herrera, 1995), Egypt (Lamberti et al., 1996), Libya (Siddiqui et al., 1987), Nigeria (Khan et al., 1993) and South Africa (Knoetze et al., 2000). Except its direct damage to root system, $X$. italiae has been reported to be a vector of GFLV according to Cohn et al. (1970).

Identification of nematodes based on morphology and morphometrics is time-consuming and difficult due to overlapping of many characteristics. The use of morphology has, therefore, been augmented by techniques based on molecular characters which generally result in simple band patterns that are easily interpreted by non-specialists. Recently polymerase chain reaction (PCR)-based methods have been developed and successfully applied for Xiphi- nema diagnostics (Wang et al., 2003; Oliveira et al., 2005). Compared with traditional diagnostic methods, the PCR offers high specificity, sensitivity and a more rapid means of identifying large numbers of nematode samples. In this study, our objectives were to: (1) identify $X$. italiae using species specific primers, (2) obtain nucleotide sequences of the mitochondrial and ribosomal DNA.

\section{Materials and methods}

Soil samples were collected from the rhizosphere of grapevines at Moča, near the border with Hungary in the southwestern region of the Slovak Republic. Nematodes were extracted from soil by a modified sieving and decanting method (Brown \& Boag, 1988) as follows: $500 \mathrm{~g}$ of soil was stirred thoroughly by hand to suspend all particles in 3 liters of tap water in a bucket. The resulting suspension was washed quickly into another bucket through a sieve of $2.0 \mathrm{~mm}$ aperture and the suspension was carefully stirred again. After 10 seconds sedimentation, the suspension was slowly decanted through a $80 \mu \mathrm{m}$ sieve. The residue on the sieve was carefully washed from the opposite side of the sieve with a gentle jet of tap water over a smaller bucket and after 10 seconds the suspension was again gently washed through same sieve. This process was repeated till the residue was without soil particles and water at washing was clean. At the end of the last washing process, the residue was concentrated at one part of sieve by bowing and the residue was rinsed from the sieve to a glass beaker. After sedimentation live individuals of $X$. italiae were hand picked directly from the suspension under a stereomicroscope, preserved in $1 \mathrm{M} \mathrm{NaCl}$ and posted to the Czech Republic. Upon arrival, nematodes were stored at $-20^{\circ} \mathrm{C}$ until DNA extraction was performed. Morphological and morphometrical characteristics from the same population were previously studied by Lišková et al., 1993, Lišková et al., 1995; Lišková, 1996. 
Table 1. Primers used to amplify cox1-mtDNA, ITS2-rDNA, D2/D3 expansion segments of 28S-rDNA and 18S-rDNA

\begin{tabular}{lllll}
\hline \multicolumn{1}{c}{ Gene } & Primer name & Direction & \multicolumn{1}{c}{ Primer sequence 5' - 3' } & \multicolumn{1}{c}{ Reference } \\
\hline coxl-mtDNA & COIF & forward & GAT TTT TTG GKC ATC CWG ARG & He et al., 2005a \\
coxl-mtDNA & COIR & reverse & CWA CAT AAT AAG TAT CAT G & He et al., 2005a \\
28S-rDNA & D2A & forward & ACA AGT ACC GTG AGG GAA AGT TG & De Ley et al., 1999 \\
28S-rDNA & D3B & reverse & TCG GAA GGA ACC AGC TAC TA & De Ley et al., 1999 \\
ITS2-rDNA & WDF & forward & AGA CAC AAA GAG CAT CGA CT & Kumari et al., 2009 \\
ITS2-rDNA & VRAIN 2R & reverse & TTT CAC TCG CCG TTA CTA AGG GAA TC & Derycke et al., 2005 \\
18S-rDNA & 988F & forward & CTC AAAGAT TAA GCC ATG C & Holterman et al., 2006 \\
18S-rDNA & 1912R & reverse & TTT ACG GTC AGA ACT AGG G & Holterman et al., 2006 \\
18S-rDNA & $1813 \mathrm{~F}$ & forward & CTG CGT GAG AGGTGA AAT & Holterman et al., 2006 \\
18S-rDNA & 2646R & reverse & GCT ACC TTG TTA CGA CTT TT & Holterman et al., 2006 \\
\hline
\end{tabular}

Total genomic DNA was extracted from each single nematode with the protocol previously described (Stanton et al., 1998). Single females were added in $2 \mathrm{ml}$ Eppendorf microtubes containing $20 \mu \mathrm{l}$ of $0.25 \mathrm{M} \mathrm{NaOH}$ under a binocular microscope and incubated overnight at room temperature, thereafter heated to $99^{\circ} \mathrm{C}$ for $3 \mathrm{~min}$. Afterwards 10 $\mu 1$ of $0.25 \mathrm{M} \mathrm{HCl}$, and $5 \mu \mathrm{l}$ each of $0.5 \mathrm{M}$ Tris- $\mathrm{HCl}(\mathrm{pH} 8)$ and $2 \%$ Triton X-100 were added and the mixture was incubated for another $3 \mathrm{~min}$ at $99^{\circ} \mathrm{C}$. The DNA was either used directly after extraction or stored at $-20^{\circ} \mathrm{C}$.

For specific amplification of $X$. italiae, a species-specific sense primer ITA26 (5'-GAAATAAGAACCCTGAAAAA GATAGG-3') and an antisense primer (3'-GAATAGCCA CCTAGTGAGCCGAGCA-5') were used (Wang et al., 2003). The PCR was performed in a $25 \mu \mathrm{l}$ total volume containing 1 PCR bead (GE Healthcare, Buckinghamshire, UK), $20 \mu$ double distilled sterile water, $2.0 \mu \mathrm{l}$ each primer $(10 \mathrm{pmol} / \mu \mathrm{l})$ (synthesized by Generi Biotech, Hradec Králové, Czech Republic), and to this $1.0 \mu \mathrm{l}$ of DNA was added as a template for PCR. A negative control (sterilized water) was included in all PCR experiments. All PCR reactions were performed on a DNA Engine PTC-1148 thermal cycler (Bio-Rad). The DNA was subjected to a PCR with the following specifications: first denaturation for $3 \mathrm{~min}$ at $94^{\circ} \mathrm{C}, 40$ cycles with $30 \mathrm{~s}$ at $94^{\circ} \mathrm{C}, 30 \mathrm{~s}$ at $55^{\circ} \mathrm{C}, 30 \mathrm{~s}$ at $72^{\circ} \mathrm{C}$ and a final extension at $72^{\circ} \mathrm{C}$ for 10 min. An aliquot $(5 \mu \mathrm{l})$ of each amplification reaction was mixed with $1.5 \mu$ l of $6 x$ loading dye (Fermentas, MBI) and electrophoresed in high resolution $1.5 \%$ agarose gel and run in TAE (Tris-Acetate-EDTA) buffer. The bands were visualized and photographed under UV (312 nm) after syber safe $(1 \mu \mathrm{g} / \mathrm{ml})$ binding to the DNA fragments. A 100 base pair marker (Fermentas) was included on gel.

Four regions (cox1, ITS2, 18S and 28S) of mitochondrial and ribosomal DNA were amplified using published primers (Table 1). The $18 \mathrm{~S}$ gene was amplified in two fragments. Primer combination was $988 \mathrm{~F}+1912 \mathrm{R}$ for the first fragment and $1813 \mathrm{~F}+2646 \mathrm{R}$ for the second fragment. The cycling profile for cox 1, ITS2, 18S and 28S were the same as described by Kumari et al. (2009). PCR mix was the same as used for the amplification with specific primers. Aliquots of PCR analysed by electrophoresis and the remaining products were purified using a High Pure Product
Purification kit (Roche Diagnostics GmbH, Mannheim, Germany) and sequenced in both directions using each primer pair one forward and one reverse (Macrogen, Korea). Sequencher ${ }^{\mathrm{TM}} 4.8$ (Genes codes. Corp., Ann Arbor, MI, USA) was used to assemble and view each sequences and check for base-calling errors.

\section{Results and Dicussion}

A single fragment of approximately $414 \mathrm{bp}$ was amplified for all individuals of $X$. italiae and no PCR products were obtained in the negative water control (Fig. 1) or DNA template of $X$. brevicollum, $X$. dentatum, $X$. diversicaudatum, X. pachtaicum, X. simile and X. vuittenezi (data not shown). Identification of all individuals was reliably confirmed using species-specific primers of ribosomal DNA (Wang et al., 2003). The PCR assay described here is a reliable and rapid means of identification of $X$. italiae. The assay allowed the verification of results from a morphological and morphometrical study of this nematode species in the Slovak Republic (Lišková et al., 1993, Lišková et al., 1995; Lišková, 1996).

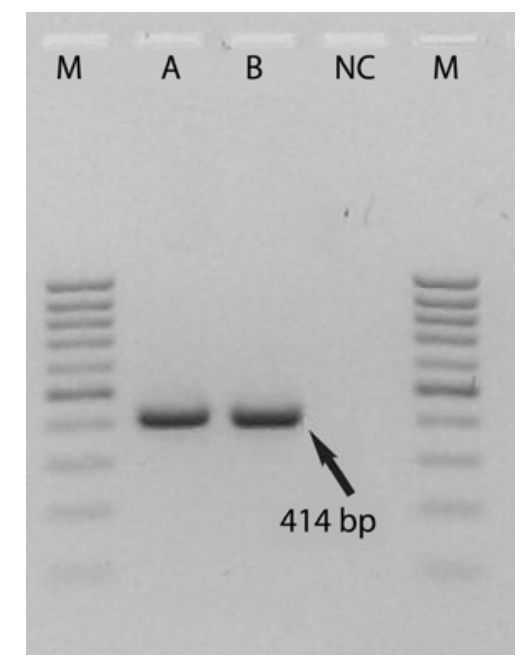

Fig. 1. Electrophoresis of the amplified products from single females of Xiphinema italiae: lane M - 100 bp DNA ladder (Fermentas); lane A - female 1; lane B - female 2; NC - water control 
The sequences of one individual (out of two) for four molecular markers were deposited at the NCBI (National Center for Biotechnology Information) database and their accession numbers are FJ713151 (cox1); FJ713152 (ITS2); FJ713153 (D2/D3); FJ713154 (18S). The length of the four loci was $416 \mathrm{bp}$ for $\operatorname{cox} 1,601 \mathrm{bp}$ for ITS2 (including the 3 end of the $5.8 \mathrm{~S}$ gene and the 5 end of the $28 \mathrm{~S}$ gene), 844 bp for D2/D3 and 1649 bp for 18S. Identical sequences were obtained for the two individuals for all four loci. The nucleotide sequences of four loci were sequenced from the same DNA of a single individual. The sequences obtained were compared by BLAST (Basic Local Alignment Search Tool) in NCBI. BLAST results of D2/D3 sequence showed strong similarities with $X$. italiae accession no. AY601613 (He et al., 2005b) and three nucleotide difference was observed. The cox1, ITS2 and 18S sequences of $X$. italiae are not available in GenBank but the BLAST hits were obtained with Xiphinema species. BLAST results showed first identities with $X$. citricolum accession numbers AM086693 (Lazarova et al., 2006) for cox1 and $X$. vuittenezi accession numbers EU444017 and EF614267 (Kumari et al., 2009) for ITS2 and 18S respectively.

\section{Acknowledgements}

The work was supported by the National Agency of Agriculture Research of the Czech Republic, Project number QG60123.

\section{Reference}

BARSI, L., LAMBERTI, F. (2003): Morphometrics of adults and juvenile stages of three longidorid nematodes (Nematoda: Dorylaimida) from Vojvodina Province, Northern Serbia. Nematol. Medit., 31: 65 - 85

Brown, D. J. F., BOAG, B. (1988): An examination of methods used to extract virus-vector nematodes (Nematoda: Longidoridae and Trichodoridae) from soil samples. Nematol. Medit., 16: 93 - 99

Cohn, E., Tanne, E., Nitzany, F. E. (1970): Xiphinema italiae, a new vector of grapevine fanleaf virus. Phytopathology, 60: $181-182$

De Ley, P., FÉliX, M. A., Frisse, L. M., NAdler, S. A., SternBerG, P. W., ThOMAs, W. K. (1999): Molecular and morphological characterisation of two reproductively isolated species with mirror-image anatomy (Nematoda: Cephalobidae). Nematology, 1: $591-612$

Derycke, S., Remerie, T., Vierstraete, A., Backeljau, T., VAnfleteren, J., VincX, M., Moens, T. (2005): Mitochondrial DNA variation and cryptic speciation within the free-living marine nematode Pellioditis marina. Mar. Ecol. Prog. Ser., 300: 91 - 103

Dias-Silveira, M.F., Herrera, J.O. (1995): Principales problemas nematologicos en Cuba. In: Congresso International de Nematologia Tropical, Rio Quente, Brazil. Proceedings, $161-171$

He, Y., Jones, J., Armstrong, M., Lamberti, F., Moens, M. (2005a): The mitochondrial genome of Xiphinema americanum sensu stricto (Nematoda: Enoplea): Considerable economization in the length and structural features of encoded genes. J. Mol. Evol., 61: 819 - 833

He, Y., Subbotin, S. A., Rubtsova, T. V., Lamberti, F., Brown, D. J. F., MoEns, M. (2005b): A molecular phylogenetic approach to Longidoridae (Nematoda: Dorylaimida). Nematology, 7: $111-124$

Holterman, M., Wurff, A. V. D., Elsen, S. V. D., Megen, H. V., Bongers, T., Holovachov, O., BAKKer, J., HELDER, J. (2006): Phylum-wide analysis of SSU rDNA reveals deep phylogenetic relationships among nematodes and accelerated evolution toward crown clades. Mol. Biol. Evol., 23: 1792 - 1800

Khan, F. A., ERInle, I. D., ChIndo, P. S. (1993): Survey of plant parasitic nematodes associated with grapevine in 4 northern states of Nigeria and observations on grapevine fanleaf virus. J. Afr. Zool., 107: $505-510$

Knoetze, R., Burger, J. T, Meyer, A. J. (2000): Discrimination of some Xiphinema species from South Africa by rDNA-RFLP analysis. Afr Plant Protect., 6: 25 - 30

Kumari, S., DECRAEMER, W., Traversa, D., LiŠKOVÁ, M. (2009): Molecular and morphological delineation of Longidorus poessneckensis Altherr, 1974 (Nematoda: Dorylaimida). Eur. J. Pl. Path., 123: 125 - 137

LAmberti, F., Agostinelli, A., Radicci, V. (1996): Longidorid nematodes from Northern Egypt. Nematol. Medit., 24: $307-339$

Lazarova, S. S., Malloch, G., Oliveira, C. M. G., HÜBSCHEN, J., NeILSON, R. (2006): Ribosomal and mitochondrial DNA analyses of Xiphinema americanum-group populations. J. Nematol., 38: $404-410$

LiŠKOVÁ, M. (1996): The males of Longidorus leptocephalus and Xiphinema italiae (Nematoda: Longidoridae) from Slovakia. Helminthologia, 33: 87- 92

Liskova, M., Brown, D. J. F., TAYLOR, C. E. (1995): The occurrence and distribution of Longidoridae and Trichodoridae in the Slovak Republic. Rus. J. Nematol., 3: $49-60$

Liskova, M., LAmberti, F., SABOVÁ, M., VAlockÁ, B., Agostinelli, A. (1993): First record of some species of longidorid nematodes from Slovakia. Nematol. Medit., 21: $49-53$

Martelli, G. P., Cohn, E., Dalmasso, A. (1966): A redescription of Xiphinema italiae Meyl, 1953 and its relationship to Xiphinema arenarium Luc et Dalmasso, 1963 and Xiphinema conurum Siddiqi, 1964. Nematologica, 12: $183-194$

NAGY, P. (1999): New faunistic record for Longidorus attenuatus Hooper, 1961 and Xiphinema italiae Meyl, 1953 (Nematoda: Longidoridae) in Hungary. Növényvédelem, 35: 15

Oliveira, C. M. G., Fenton, B., Malloch, G., Brown, D. J. F., NeILSON, R. (2005): Development of species-specific primers for the ectoparasitic nematode species Xiphinema brevicolle, $X$. diffusum, $X$. elongatum, $X$. ifacolum and $X$. longicaudatum (Nematoda: Longidoridae) based on ribosomal DNA sequences. Ann. Appl. Biol., 146: $281-$ 288

Peneva, V., Choleva, B. (1992): Nematodes of the fa- 
mily Longidoridae from forest nurseries in Bulgaria. II. The genus Xiphinema Cobb, 1913. Helminthology, 32: 46 $-58$

PolinOVsKiJ, A. I. (1979): Species composition and geographic distribution of nematodes of the family Longidoridae (Nematoda: Dorylaimoidea) on grapevines of the Moldavian SSR, USSS. Izv. Akad. Nauk Mold. SSR. Ser. Biol. chim. Nauk, 11: $37-48$

RomAnenKO, N. D. (1985): Distribution of Longidoridae nematodes in fruit and berry plantations in the USSR. In: Progressive methods of soft fruit cultivation and breeding. Sbornik Nauch. Trud. Moscov, 112 - 120

Siddiqui, Z. A., Rashid, A., FARooqi, N., Bisheya, F. (1987): A survey of plant parasitic nematodes associated with citrus in Libya and trials on chemical control. Indian J. Nematol., 17: $76-80$

Stanton, J. M., McNicol, C. D., Steele, V. (1998): Non-manual lysis of second-stage Meloidogyne juveniles for identification of pure and mixed samples based on the polymerase chain reaction. Australas. Plant Path., 27: 112 $-115$

Teliz, D, LANDA, B. B, RAPOPORT, H. E., CAMAChO, F. P., DiAZ, J. R. M., CASTILlO, P. (2007): Plant parasitic nematodes infecting grapevine in southern Spain and susceptible reaction to root-knot nematodes of rootstocks reported as moderately resistant. Plant Dis., 91: 1147 - 1157

Tzortzakakis, E. A., Pateras, D., Charoulis, A. (2006): Occurrence of Xiphinema species in grapevine areas of Tyranvos with comments on the distribution of $X$. italiae in Greece. Helminthologia, 43: $186-187$

Wang, X., Bosselut, N., Castagnone, C., Voisin, R., ABAD, P., ESMENJAUd, D. (2003): Multiplex polymerase chain reaction identification of single individuals of the longidorid nematodes Xiphinema index, X. diversicaudatum, $X$. vuittenezi, and $X$. italiae using specific primers from ribosomal genes. Phytopathology, 93: 160 - 166 